Relations industrielles

Industrial Relations

\title{
Léandre Maillet, Psychologie et organisations. L'individu dans son millieu de travail
}

\section{Alain Larocque}

Volume 46, numéro 1, 1991

URI : https://id.erudit.org/iderudit/050664ar

DOI : https://doi.org/10.7202/050664ar

Aller au sommaire du numéro

Éditeur(s)

Département des relations industrielles de l'Université Laval

ISSN

0034-379X (imprimé)

1703-8138 (numérique)

Découvrir la revue

Citer ce compte rendu

Larocque, A. (1991). Compte rendu de [Léandre Maillet, Psychologie et organisations. L'individu dans son millieu de travail]. Relations industrielles / Industrial Relations, 46(1), 244-245. https://doi.org/10.7202/050664ar

Tous droits réservés @ C Département des relations industrielles de l'Universite Laval, 1991
Ce document est protégé par la loi sur le droit d'auteur. L’utilisation des services d'Érudit (y compris la reproduction) est assujettie à sa politique d'utilisation que vous pouvez consulter en ligne.

https://apropos.erudit.org/fr/usagers/politique-dutilisation/ 
Dans l'ensemble, la contribution originale de l'auteur consiste à réunir dans un seul volume l'apport de disciplines, tant des sciences humaines que de la physique et de la biologie, à l'analyse et la compréhension des organisations. En effet, on ne saurait accéder à une connaissance convenable des structures et du fonctionnement des organisations en privilégiant une vision en particulier et en se privant ainsi de l'éclairage fourni par d'autres métaphores. Le recours à diverses images permet une analyse plus raffinée des problèmes auxquels font face les organisations et facilite également la recherche de solutions plus appropriées.

Laurent BÉLANGER

Université Laval

Psychologie et organisations - L'individu dans son milieu de travail, par Léandre MAILLET, publié dans la Collection «Psychologie Industrielle et Organisationnelle», sous la direction de Yvan Bordeleau, Montréal, Agence d'ARC, 1988, 576 p., ISBN 2-89022-124-5

Comme l'écrit fort justement l'auteur sur la jaquette de son ouvrage «ce livre tente d'apprivoiser le lecteur face aux principaux aspects humains de l'organisation» et, pourrions-nous ajouter, particulièrement pour ceux et celles qui abordent l'étude des organisations et des sciences sociales. C'est un ouvrage de facture classique. L'auteur puise aux différentes disciplines des sciences humaines, davantage à celle de la psychologie appliquée au monde des organisations. Il se situe à cet égard dans la foulée des quelque six ouvrages parus en français ces dernières années.

Léandre Maillet parvient à intégrer, dans une perspective systémique, les principales données de la psychologie moderne pour mieux en comprendre les comportements de l'individu dans son milieu de travail. Le support bibliographique est impressionnant: les références sont nombreuses, pertinentes et récentes. Il aurait été assurément intéressant pour le lecteur francophone d'en trouver davantage en français, mais c'est là un état de fait qui échappe en partie à l'auteur.

Après avoir présenté un aperçu historique de la notion de comportement organisationnel, l'auteur s'attarde par la suite aux facteurs individuels (la perception, la communication, la motivation, l'apprentissage) pour ensuite aborder les facteurs à caractère social liés à l'organisation et au fonctionnement des groupes dans l'organisation (la dynamique des groupes, les conflits inter groupes, le pouvoir et le leadership). Ce manuel traite dans ses derniers chapitres du changement et du développement dans les organisations.

Le lecteur qui y chercherait une vision nouvelle, originale ou renouvelée du fonctionnement de l'individu en milieu organisationnel s'en trouvera probablement déçu comme d'ailleurs celui qui y chercherait des données inédites de l'auteur. Ce n'est pas la fin poursuivie par Léandre Maillet. Il vise un objectif essentiellement pédadogique en support à l'enseignement de ces matières. Il consigne et intègre dans un manuel les principales données de la psychologie moderne appliquées au monde des organisations afin de mieux en comprendre certains principes régissant le comportement individuel dans le cadre de ses activités de travail. Pour parvenir à cette visée pédagogique à chaque chapitre il fixe les objectifs d'apprentissage poursuivis, fait une mise en situation pour introduire la matière, soumet au lecteur des sujets de discussion et des études de cas. C'est ce qui fondamentalement lui donne son caractère de manuel en support à l'enseignement. 
On aurait souhaité que l'éditeur mette autant de soins à la présentation visuelle de l'ouvrage qu'en a mis l'auteur à la rédaction et l'organisation pédagogique du texte. Une prochaine édition devrait permettre, si l'on veut assurer la pérennité d'un tel ouvrage, d'en améliorer le caractère typographique et l'illustration du texte. L'ajout d'index thématiques et des auteurs cités contribuerait à en faire un instrument utile et fonctionnel que l'on conserve et continue de consulter... même le cours terminé!

Alain LAROCQUE

Université Laval

The Sociology of Management, by Mike I. Reed, New York, Harvester Wheatheaf, 1989, p. $X+182$, ISBN 0-7450-0570-5.

This is the attempt to cumulate the sociological knowledge of management as a social practice geared to the assembly and regulation of other social practices concerned with the transformation of the environmental conditions encompassing socio-economic life. Technological change leads to the automated administration; there is a progressing erosion of the privileged employment position of higher-level white-collar workers; the technologically induced deskilling and rationalisation weakens the bargaining position of lower and middle managers; pressures to achieve increased organizational flexibility make managers vulnerable; managers remain a highly differentiated group and they miss integration allowing to promote common interests; the process whereby individuals become credentialled for entry into higherlevel positions is not consolidated; the dependence on employer remains high and actually grows with the progress of capital concentration; the existing knowledge and skill base is not strong enough to permit the achievement of social closure. There is a tendency to question the future of management as an autonomous profession. On the other hand, learning of it becomes more complex and fashionable and the management consulting business is growing all around the world.

The sociological perspectives on management summarized by the author present it either as a rationally designed tool for the realisation of instrumental objectives (the explanatory model of systems theory), or as the negotiated social process for the regulation of interest group conflict (the explanatory model of action theory), or as the control mechanism geared to the extraction of maximum surplus value (the explanatory model of marxist theory). The dilemmas of managerial practice are still not adequately acknowledged at the theoretical level. "None of the three analytical perspectives we have discussed exhibits a sufficient degree of theoretical and methodological sensitivity to the ambiguities of managerial practice" (p. 17). The author suggests the practice perspective in which "management is treated as a process or activity aimed at the continual recoupling or smoothing over of diverse and complex practices always prone to disengagement and fragmentation (...). Work organizations are seen as points of intersection for a wide range of social practices that are subjected to various strategies of institutional combination and recombination"' (p. 21). From this perspective, management constitutes both a mechanism through which conflict over the possession and control of resources necessary for primary productive activity can be, at least temporarily, regulated, and the process which provides a medium for struggle over the institutional arrangements through which this regulation is achieved.

A conception of managerial control as a loosely coupled network of co-ordinating practices geared to the assembly of productive activity helps to integrate the variety of concerns: appreciation of specific parameters of the technical, economic and organizational nature, 